1 Groundwater resource modelling for public water supply management in 2 London

Michael A Jones ${ }^{1 *}$, Andrew G Hughes ${ }^{2}$, Christopher R Jackson ${ }^{2}$, Jan van Wonderen ${ }^{3}$

${ }^{1}$ Thames Water, Rose Kiln Court, Rose Kiln Lane, Reading, RG54PQ

${ }^{2}$ British Geological Survey, Kingsley Dunham Centre, Keyworth, Nottingham, NG12 $5 G G$

${ }^{3}$ Mott MacDonald, Demeter House, Station Road, Cambridge, CB1 2RS

*Corresponding author: michael.jones@thameswater.co.uk

Number of words: 4900

Running title: Groundwater resource modelling in London

\begin{abstract}
In London, groundwater abstractions for public supply are predominantly from the Chalk aquifer. However, water resource pressures put existing abstractions at risk and often require complex analysis to support new source development. Thames Water develops and uses regional groundwater models for such analysis to support communication with stakeholders such as the Environment Agency, the environmental regulator of England and Wales. Using two case studies, the importance of regional models as Thames Water assets is demonstrated.

While Thames Water has developed regional models as a context for sub-catchment scale analysis of groundwater source development, they are subsequently used to address other issues. As a result, the models are updated regularly, enhancing both conceptual understanding and calibration. These models cost less than $1 \%$ of the capital cost of new water source schemes. However, as they are enhanced and applied more widely, the models accrue further value as active decision support tools.

Regional model usage to investigate a range of local systems and interactions is of particular value to Thames Water. It is important, however, to appreciate and promote the clarity and consistency generated when stakeholder-specific issues can be analysed within an agreed regional model framework.
\end{abstract}

\title{
Abstract ends
}

Thames Water provides a public water supply to around 8.5 million customers in London and the Thames Valley, an area largely covering the River Thames catchment (Fig. 1). On average, around 2,600 million litres per day (Ml/d; 2.6 million $\mathrm{m}^{3} / \mathrm{d}$ ) of potable water are put into supply to meet demand across the supply area, with this being drawn from a water resource base comprising about 35\% groundwater and $65 \%$ from river water. However, owing to catchment water resource pressures, some groundwater abstractions are at risk of licence reductions, while the development of new abstractions and management of operational abstractions can require complex hydrogeological analysis. As a result, to justify development of new sources and to define operational abstraction management to mitigate environmental impact, Thames Water develops and uses regional groundwater models to assess catchment and subcatchment scale issues. 
The importance of Thames Water's regional groundwater models as business assets is presented here. This is demonstrated through their use, for example, in supporting the development of new abstractions with capital values of around $£ 35$ million up to about $£ 50$ million. In addition, the potential is considered for deriving further value from these models in future.

\section{Water supply and hydrogeology in the Thames Water area}

Fig. 1 shows simplistically that the underlying solid geology of the River Thames catchment is dominated by low permeability clays. For example, the Tertiary London Clay underlies much of the south-eastern part of the catchment, including London, with the Cretaceous and Jurassic Gault and Oxford Clays underlying much of the north-western catchment. Clearly, however, there are major aquifers interbedded with these clays, specifically the Cretaceous Chalk and Lower Greensand in the central and south-eastern parts of the catchment, and the Jurassic Oolitic Limestone in the west. In addition to these solid geological aquifers, the overlying superficial Gravels in the lower River Thames catchment have some local importance for water supply. The relative, licensed contribution to public water supply made by Thames Water's 180 groundwater sources from each of these aquifers is as follows:
(a) Gravels
$1 \%$
(b) Chalk
$90 \%$
(c) Lower Greensand
$4 \%$
(d) Oolitic Limestone
$5 \%$

The importance of the Chalk as a source of public water supply is clear. Groundwater abstractions from the Chalk are dominated by withdrawal from unconfined aquifer areas, and only about $10 \%$ of Thames Water groundwater abstractions, by licensed volume, are from deep, confined aquifer units. However, in London the confined Chalk (Fig. 1) has again become an increasingly important source for public and private water supply. This has been driven partly by delivery of the GARDIT (General Aquifer Research, Development and Investigation Team) Strategy, in the late $20^{\text {th }}$ century and early $21^{\text {st }}$ century, to mitigate the risk from rising groundwater levels (Jones 2007). In addition, groundwater in the confined Chalk of London is increasingly being used as a source of geothermal energy and a sink for heat rejected for new developments (Fry 2009).

\section{Groundwater resource challenges and opportunities}

Within the Thames Water supply area several challenges influence the availability and development of groundwater resources. These challenges include low river flows and their consequential link with abstraction, as well as a general lack of available water resources, making source development difficult. This is true for the whole River Thames catchment, the Thames Water supply area as well as London specifically. The water resource challenges in London are set within the framework provided by the Environment Agency's Catchment Abstraction Management Strategies (CAMS) for London (Environment Agency 2006) and the Darent/Cray catchment (Environment Agency 2007). For both of these Chalk dominated catchments, the CAMS establish that the water resource status ranges from 'no water available' to 'over-abstracted' where actual abstraction results in river flow targets not 
being achieved. A fuller explanation of the CAMS regulatory process is provided by Although CAMS is a relatively recent development, it broadly reflects the general water resource status as previously understood. In London, the water resource challenge of low river flows, where groundwater abstractions may be affecting river baseflows and associated aquatic habitats, is a real issue with a long history. Such potential abstraction impacts now often require investigation under the Environment Agency's Restoring Sustainable Abstraction programme (RSAp), with reductions in licensed abstraction quantities being a potential outcome; see Whiteman et al. (this volume) for a fuller explanation. In London, investigations of abstraction impacts on the River Darent have ultimately resulted in a phased reduction of Thames Water's licences as part of the Darent Action Plan. The final phases of this plan have resulted in the development of the new Bean Wellfield to compensate the licence reductions. This development is discussed as Case Study 1.

In the confined Chalk beneath London, groundwater levels declined during the 19th and early 20th century, then recovered in the second half of the 20th century. This was the result of groundwater abstraction that continued to grow until the 1940s resulting in over-exploitation of the aquifer and declining groundwater levels. The consequence was a reduction in abstraction yields, which was accompanied by a decline in abstraction for industry and manufacturing within London after the 1939-45 war. Despite this reduction in abstraction, Chalk groundwater levels continued to decline until the mid-1960s, reaching a depth of almost $90 \mathrm{~m}$ below sea level in the centre of the London Basin, then recovered dramatically at maximum rates of 3 metres per year. During this period of groundwater level decline and initial recovery, the confined Chalk aquifer, and the overlying Basal Sands aquifer, became partially dewatered for a number of decades. The pattern of groundwater level evolution in the $20^{\text {th }}$ century is illustrated by the groundwater hydrograph from the Trafalgar Square borehole in the centre of the London Basin (Fig. 2, after Jones et al. 2005).

The rise of Chalk groundwater levels after 1965 posed a risk of structural damage to tall buildings with deep basements, service tunnels and underground railways, via changed geotechnical properties of founding clays and settlement (CIRIA 1989). As the dewatered Chalk refilled, the hydraulic gradient driving inflow from the Chalk outcrop declined and the rate of groundwater level rise slowed, but the risk was ultimately mitigated by a strategy of increased abstraction promoted by GARDIT. This strategy, led by Thames Water, London Underground and the Environment Agency, delivered an increase of over $50 \mathrm{Ml} / \mathrm{d}$ in licensed abstraction, predominantly for public water supply (Jones 2007). Although the recovery of groundwater levels was initially perceived as a risk, it provided a wider opportunity for potential development of additional groundwater abstractions as groundwater storage increased. This opportunity in part underlies the development of the ELRED Wellfield discussed here as Case Study 2.

Abstraction increases delivered under the GARDIT Strategy have begun to cause groundwater level declines; notably, in south-west London groundwater levels have fallen at rates of around 3-4 m/year when such abstractions have been operational (Environment Agency 2010). As a result, the opportunity for managing groundwater storage is developing to ensure that maximum groundwater levels do not impact subsurface infrastructure, with minimum levels defining a water resource limit and/or 
153 a level at which other abstractors are derogated (Jones 2007). Such management

154 would need to be driven by artificial recharge, and could deliver a south London

155 equivalent to Thames Water's operational North London Artificial Recharge Scheme

156 (NLARS) (Harris et al. 2005; O’Shea and Sage 1999). The potential for developing a

157 South London Artificial Recharge Scheme (SLARS), by modifying existing into dual

158 abstraction-injection boreholes is described in Jones et al. (2005).

159

160

161

162

163

164

165

166

167

168

169

170

171

172

173

174

175

176

177

178

179

180

181

182

183

184

185

186

187

188

189

190

191

192

193

194

195

196

197

198

199

200

201

202

203

\section{Groundwater resource modelling framework}

Thames Water's investigation of each of the groundwater resource challenges and opportunities outlined above has been supported by the development of conceptual and numerical models. The approach taken for developing groundwater models is driven by supply-demand balance, i.e. can sufficient quantity of water be abstracted sustainably at the required time to meet demand. This requires a "bottom up" approach based on developing a groundwater model to answer a specific question. However, once a model has been developed, then it is often re-used to answer other questions, often in different locations. Examples of the questions that can be considered include the sustainability of a proposed wellfield next to a quarry (Case Study 1) or the impact of abstraction in inducing brackish water into the aquifer (Case Study 2). This leads to an approach that is focussed on a particular issue in a geographical area at a particular time. Once the model has been developed and used, then the focus of model development can be moved elsewhere. The corollary of this developmental process is that groundwater models are regularly updated, both in terms of the conceptual understanding built into the models and also the time period for the historical simulation. The latter means that the recharge model is updated along with other data, such as groundwater and surface water abstractions, which is usually accompanied by a calibration update.

For the assessment of some hydrogeological systems in the River Thames catchment, groundwater models have been developed by the Environment Agency Thames and Southern Regions. Thames Water, as a key stakeholder, has had some involvement in these model developments, and promoted initial collaboration with the Environment Agency on development of Thames Water's London Basin Groundwater Model. However, during the last 10 years, Thames Water has developed and used its own regional Chalk groundwater models to support hydrogeological analysis during resource investigations, source development and licence applications. This began in 1999-2000 when Thames Water and the Environment Agency initially developed the London Basin Groundwater (LBG) model jointly to assess regional rising groundwater level issues. However, Thames Water actively developed and maintained the LBG model to analyse specific groundwater exploration and source development issues in various parts of the London Basin, including the NLARS, SLARS and ELRED operations. Essentially, sufficient business drivers existed to justify capital expenditure on model development and application. Subsequently, this has led to Thames Water developing further regional models to include the Darent and Cray catchments, as well as catchments feeding the middle reaches of the river Thames to address specific source developments.

These regional models provide a framework for understanding Chalk groundwater systems and enable assessment of specific sustainability issues and risks to source viability. As they are often used to investigate abstraction impacts and secure abstraction licences, the sensible aspiration is to have models that are agreed with the 
Environment Agency, the environmental regulator and counterpart stakeholder to Thames Water as water supplier. Broadly an agreed model is considered to mean a groundwater model that is:

(a) a reasonable representation of the underlying conceptual understanding (the conceptual model) within the context of existing uncertainty;

(b) appropriate to explore the question being considered;

(c) able to provide sufficient confidence in its output to support decision making.

Although Thames Water's models have been used to secure abstractions and make joint environmental impact decisions, indicating agreement to model acceptability for use, only one of Thames Water's models is currently shared with the Environment Agency. This is the London Basin Groundwater (LBG) model. Agreed, shared regional groundwater models would provide a more effective framework for the analysis of catchment and sub-catchment scale issues.

The importance of Thames Water's regional groundwater models as business assets is considered through two case studies. Each is an example of catchment and subcatchment scale modelling to support the hydrogeological assessment and licensing of the Bean Wellfield, north Kent (Case Study 1), and to define operational abstraction strategies to mitigate the risk of environmental impact from the ELRED Wellfield, east London (Case Study 2).

\section{Case Study 1 - Bean wellfield: New source licensing}

Investigations of impacts from bank-side Chalk and Lower Greensand abstractions on the River Darent have resulted in a phased reduction of some of Thames Water's licences as part of the Darent Action Plan. A large chalk pit (Eastern Quarry) with potential surplus groundwater from dewatering, located east of the River Darent, was targeted to compensate for these reductions, including those at Horton Kirby and Eynsford. Between 2002 and 2005, a series of boreholes were drilled in the interfluve east of the River Darent to intercept groundwater flowing to the quarry; these were successfully developed into the Bean Wellfield, feeding the Lane End water treatment works (Fig. 3). However, the interfluve hydrogeology is complex with karstic flow tubes influencing groundwater flow in the Chalk, and the overlying Clay-with-Flints routing runoff to focussed recharge. Furthermore, historic quarry dewatering has influenced groundwater heads and flows, while redevelopment of the quarry will result in management of the groundwater to a higher base level. Within this complex framework, it was essential to ensure that the wellfield abstraction would have no significant impact on the River Darent, it would be sustainable and, therefore, could be licensed by the Environment Agency. This analysis was supported using the Swanscombe groundwater model.

The Swanscombe model is a three layer, regional model of the Chalk, developed for Thames Water by the British Geological Survey using the ZOOM suite of objectoriented codes (Spink et al. 2003). The models consist of a recharge model, ZOODRM (Hughes et al. 2008), a groundwater flow model ZOOMQ3D (Jackson et al. 2005) and a particle tracking code ZOOPT (Stuart et al. 2006). A summary of the recharge model is provided by Hughes et al. (2003) and the groundwater flow model by Jackson et al. (2003). The model covers an area of about $810 \mathrm{~km}^{2}$, an area extending from the River Medway in the east to the Ravensbourne-Cray interfluve in 
the west, and from the Chalk outcrop in the south to beyond the Thames Tideway in the north (Fig. 4). Calibrated for the period 1970 to 2005, the key feature of the model is the use, within the regional model limits, of refined nested grids around areas of particular interest. This included much of the Darent-Cray catchment and the wellfield-quarry area (Fig. 4), with the latter developed to enable a group pumping test to be simulated within the existing regional model (Jackson et al. 2003).

Using the Swanscombe model, it has been inferred that raising the quarry base groundwater level would reduce discharge to the quarry and therefore also reduce the loss of groundwater resource from the interfluve area. Approximately 15+ Ml/d of additional groundwater resource would be made available as a result. In addition, although groundwater levels decline in the interfluve as a result of the wellfield abstraction, groundwater levels would recover along the river Darent. As a result, the modelling has shown that the Darent baseflow is restored by abstraction relocation coupled with appropriate quarry redevelopment. The Bean Wellfield now comprises 10 boreholes abstracting from the unconfined Chalk, with yields varying from 1 to 8.5 $\mathrm{Ml} / \mathrm{d}$ and a total average licensed abstraction rate of $18.4 \mathrm{Ml} / \mathrm{d}$. Without the Swanscombe model, it is unlikely that the abstraction licence would have been secured without onerous conditions, but its cost equates to less than $1 \%$ of the capital cost of the total scheme development.

\section{Case Study 2 - ELRED: Risk minimisation analysis}

To support the assessment of many recent groundwater resource developments in the confined Chalk of London, Thames Water has used the London Basin Groundwater (LBG) model. It is a regional model covering an area of about $2300 \mathrm{~km}^{2}$, extending from the North Downs scarp slope in the south to the limit of the confined Chalk in the Chilterns (Fig. 5). It is a five layer model representing the Chalk as two layers, the Basal Sands aquifer, the Lambeth Group aquitard and the confining London Clay. The model was developed for Thames Water by Mott MacDonald using their proprietary Integrated Catchment Management Model (ICMM) code. ICMM is an integrated finite difference model that allows for variable gridding and simulation of groundwater flow in multi-layered aquifer systems. The model integrates surface water features (rivers) with the groundwater system. The key features of the model, shown in Fig. 5, are:

(a) representation of the hydrogeological compartmentalisation of the confined Chalk as aquifer blocks;

(b) aquifer blocks bounded by variable, sometimes low permeability zones, represented by hydraulic properties assigned to model cell faces;

(c) grid refinement in areas of particular interest, e.g. ELRED, as well as NLARS and SLARS (North and South London Artificial Recharge Scheme, respectively).

The model is currently calibrated for the period 1965 to 2008, covering the period of major recovery of groundwater levels and their control via groundwater development as part of the GARDIT Strategy. However, since its initial calibration in 2000, the model has been updated and enhanced in several phases undertaken to enable assessment of artificial recharge potential in SLARS, its expansion in NLARS as well as the development new abstraction sources such as ELRED. 
305 ELRED is a linear wellfield (Fig. 6), developed from part of the Channel Tunnel Rail

306 Link (CTRL) construction dewatering scheme, with a complex water treatment works 307 (WTW) at East Ham commissioned into supply in 2005 (Hamilton et al. 2008). It 308 comprises 9 abstraction sites with outputs ranging from 0.6 to $6.5 \mathrm{Ml} / \mathrm{d}$, and was 309 licensed to abstract an annual total equivalent to $22.8 \mathrm{Ml} / \mathrm{d}$. Owing to the over310 abstraction in the London Basin prior to the 1940s, brackish water intrusion had 311 occurred from the tidal River Thames estuary, then subsequently receded as 312 abstraction reduced and groundwater levels recovered. As a result, abstraction from 313 314

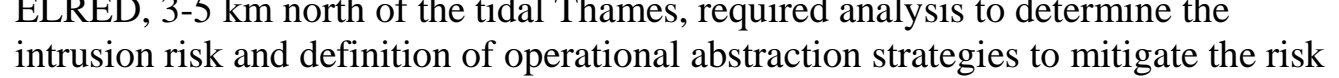
and optimise abstraction.

Using the LBG model, it was inferred that ELRED abstraction at a constant $22.8 \mathrm{Ml} / \mathrm{d}$ would, after only 5-6 years, increase flow from the River Thames into the Chalk, reaching flows comparable to those modelled in 1965. The significance of this is that in 1965 groundwater levels in the centre of the basin were at their lowest and hydraulic gradients steepest away from the river, giving rise to increased brackish water intrusion. As a result, a return to 1965 flow conditions could give rise to an increased risk of groundwater quality deterioration, which would make the licence unsustainable and inconsistent with European Water Framework Directive objectives. However, in verifying the LBG model accuracy, comparison of its output with observed groundwater level impacts suggested this to be an overly pessimistic assessment of the risk. Specifically, during simulation of the CTRL construction dewatering and ELRED test pumping, the model over-estimated the extent of groundwater level drawdown southwards to the River Thames estuary, and thus overestimated brackish water intrusion into the Chalk aquifer. Furthermore, no evidence of groundwater quality deterioration was detected during the 2-3 years of CTRL dewatering. Even though the risk of groundwater quality deterioration may have been over-estimated, a strategy of seasonally variable abstraction from ELRED was defined to address the uncertainty and aimed to:

(a) assist meeting seasonal peak demands, e.g. winter mains burst and summer peaks;

(b) assist in managing water production outage, e.g. algal blooms in raw water storage reservoirs;

(c) maintain WTW viability with a minimum abstraction to pump through the works;

(d) minimise abstraction to preserve and promote recovery of aquifer storage;

(e) maintain groundwater resources to meet sustained drought demands.

Simulation of this seasonal abstraction strategy showed a modest increase in the period of abstraction before flows from the River Thames into the Chalk reached those modelled for 1965. The critical indicator considered is flow into the Stratford Chalk block reaching just over $6,000 \mathrm{~m}^{3} / \mathrm{d}(6 \mathrm{Ml} / \mathrm{d})$. Fig. 7 shows that, with seasonal ELRED abstraction from 2004 and constant abstraction from 2008, flows into the Stratford block are modelled to reach 1965 rates in 2012. This means that the risk of groundwater quality deterioration increases after 8 years, rather than the 5-6 years initially identified. Such analysis using the LBG model has assisted in identifying options for managing operational abstraction risk, but it has also been used to promote a licence transfer from ELRED to a disused source about $2 \mathrm{~km}$ further west (Fig. 7). This has enabled abstraction to be distributed over a greater aquifer volume and thus further mitigate future risk of groundwater quality deterioration from brackish water intrusion. Without the LBG model this detailed analysis could not have been carried 
out. It has underpinned the development and risk-based operation of a $£ 35$ million new abstraction and treatment works, and enabled a deployable output benefit of almost $16 \mathrm{Ml} / \mathrm{d}$ to be secured. The cost of the LBG model development equates to less than $1 \%$ of the capital cost of the ELRED scheme development. However, the model has been used to support development of several other groundwater source schemes in London and, in practice, the LBG model costs equate to significantly less than $0.5 \%$ of the total capital costs of the schemes. This means that as the model is developed to address a wider range of issues, it accrues additional value as a decision support tool, with its total development and maintenance cost decreasing as a proportion of scheme capital costs.

\section{The future}

Since initial development of the LBG model, Thames Water has enhanced it to meet its requirements for groundwater resource exploration and development. Although Thames Water and the Environment Agency Thames Region now have a joint share in the LBG model, the Environment Agency is working towards the development of a new model of the London Basin Chalk aquifer with Thames Water as a stakeholder. In a wider context, the Environment Agency Thames Region now has or is developing a suite of regional groundwater models that partly or substantially overlap with some of Thames Water's models. In contrast, where the water supply area extends into the Environment Agency Southern Region, Thames Water has established an agreement the Environment Agency for sharing Thames Water's Swanscombe groundwater model. Clearly there is benefit and a need for stakeholders to agree on:

(a) whether regional conceptual and numerical models are reasonable representations of the groundwater system;

(b) what specific hydrogeological issues can reasonably be investigated, i.e. are they 'fit for purpose'.

Nevertheless, Thames Water will continue to maintain, develop and use its models for specific sub-catchment and catchment groundwater investigations, recognising that the models need to be set in an appropriate regional context. As analysis of stakeholder-specific issues need a regional context, the use of detailed models to represent and investigate local systems and interactions would benefit significantly from being able to draw on regional models agreed by key stakeholders. This would provide both clarity of the modelling framework as well as consistency between stakeholders. For example, local investigations may then simply extract internal conditions from an agreed regional model to form local boundary conditions, and/or set discrete, detailed model grids for different local investigations within a regional numerical model (Fig. 8). It is apparent that the Environment Agency has a key role in this framework. By its development and maintenance of agreed regional groundwater models, this could provide a framework for both regulatory investigations by the Environment Agency, as well as investigation/development work by stakeholders, including water companies.

The authors would like to thank Thames Water for permission to publish this paper. This paper is published with the permission of the Director of the British Geological Survey (NERC). 


\section{References}

Construction Industry Research and Information Association, 1989. The Engineering Implications of Rising Groundwater Levels in the Deep Aquifer Beneath London, Special Publication 69, CIRIA, London, UK.

Environment Agency, 2006. The London Catchment Abstraction Management Strategy. Final Strategy Document, April 2006. Environment Agency of England and Wales, Thames Region Report.

Environment Agency, 2007. The Darent and Cray Catchment Abstraction Management Strategy. April 2007. Environment Agency of England and Wales, Southern Region Report.

Environment Agency, 2010. Management of the London Basin Chalk Aquifer. Status Report 2010. Environment Agency of England and Wales, Thames Region Report.

Fry, V., 2009. Lessons from London: regulations of open-loop ground source heat pumps in central London. Quarterly Journal of Engineering Geology and Hydrogeology, 42, 325-334.

Hamilton, A., Riches, J., Realey, G. \& Thomas, H., 2008. 'ELRED': New water for London from old assets. Proceedings of ICE, Civil Engineering 161, 26-34.

Harris, S.J., Adams, M. \& Jones, M.A., 2005. NLARS: Evolution of an artificial recharge scheme. In: "Recharge systems for protecting and enhancing groundwater resources". Proceedings of the 5th International Symposium on Management of Aquifer Recharge, ISMAR5, Berlin, Germany, 11-16 June 2005.

Hughes, A.G., Mansour, M.M. \& Robins, N.S., 2008. Evaluation of distributed recharge in an upland semi-arid karst system: the West Bank Mountain Aquifer, Middle East. Hydrogeology Journal, 16, 845-854.

Hughes, A.G., Jackson, C.R., Rutter, H.K., Bloomfield, J.P. \& Riches, J., 2003. Development of a Distributed Recharge Model Using Object-Oriented Techniques. MODFLOW and More 2003: Understanding through Modeling - Conference Proceedings, Poeter, Zheng, Hill and Doherty. pp 490-494.

Jackson, C.R., Hughes, A.G., Ó Dochartaigh, B.E., Robins, N.S. \& Peach, D.W., 2005. Numerical testing of conceptual models of groundwater flow: A case study using the Dumfries Basin Aquifer, Scottish Journal of Geology, 41, 51-60.

Jackson, C.R., Hughes, A.G., Mansour, M.M., Spink, A.E.F., Bloomfield, J.P., Riches, J. \& Jones, M.A. 2003. Numerical Modeling of a Multiple-Well Pumping Test Using a Locally Refined Object-Oriented Groundwater Model. MODFLOW and More 2003: Understanding through Modeling - Conference Proceedings, Poeter, Zheng, Hill and Doherty. pp 383-387.

Jones, M.A., 2007. Rising groundwater in central London. Water \& Sewerage Journal, 2007 (Issue 4), 35-36.

Jones, M.A., Harris, S.J., Baxter, K.M. \& Anderson, M., 2005. The Streatham groundwater source: An analogue for the development of recharge enhanced groundwater resource management in the London Basin. In: "Recharge systems for protecting and enhancing groundwater resources". Proceedings of the 5th International Symposium on Management of Aquifer Recharge, ISMAR5, Berlin, Germany, 11-16 June 2005.

O’Shea, M. \& Sage, R., 1999. Aquifer Recharge: An Operational DroughtManagement Strategy in North London. Journal of the Chartered Institution of Water and Environmental Management, 13, 400-405.

Spink, A.E.F., Jackson, C.R., Hughes, A.G. \& Hulme, P.J., 2003. The Benefits of Object-Oriented Modeling Demonstrated through the Development of a Regional 
Groundwater Model. MODFLOW and More 2003: Understanding through Modeling - Conference Proceedings, Poeter, Zheng, Hill and Doherty. pp 336-340. Stuart, M.E., Gooddy, D.C., Hughes, A.G. \& Jackson, C.R., 2006. A Field And Modelling Study To Determine Pesticide Occurrence In A Public Water Supply In Northern England, UK. Ground Water Monitoring \& Remediation, 26, 128-136. Whiteman, M., Seymour, K., van Wonderen, J., Wilson, C., Hulme, P. \& Grout, M., this volume. Regional modelling projects in England and Wales - A regulator's perspective. In: XXXX, X., XXXX, X., XXXX, X. \& XXXX, X. (eds) Xxxxxx Xxxxxx. Geological Society, London, Special Publications, $\mathbf{X X}$, XXX-XXX.

\section{Figure Captions}

Fig.1. River Thames catchment location map showing key hydrogeological units, Thames Water water supply area and case study locations

Fig. 2. Historic Chalk groundwater level evolution at Trafalgar Square (TQ28/119) and Ashley Gardens (TQ27/88) in the centre of the confined Chalk basin, London.

Fig. 3. Detailed location map for Case Study 1 showing the Bean wellfield, other key groundwater abstractions along the River Darent, superficial and bedrock geology.

Fig. 4. The Swanscombe groundwater model, developed using the ZOOMQ3D code (Case Study 1), showing the model boundary (red), the detailed grid covering much of the River Darent and the Bean wellfield (purple) and the wellfield grid (green) used for simulating a group pumping test.

Fig. 5. The London Basin groundwater model grid (Case Study 2) superimposed on a simplified bedrock geology map of London. The conceptualisation of the confined Chalk hydrogeological compartmentalisation is illustrated by aquifer blocks bounded by variable, sometimes low permeability zones (red).

Fig. 6. Location of ELRED wellfield (Case Study 2) and the Channel Tunnel Railway (CTRL) alignment.

Fig. 7. Output from the London Basin groundwater model (Case Study 2) showing groundwater flows into (blue) and out of (red and green) the Stratford Chalk block, as influenced by abstraction from the ELRED wellfield.

Fig. 8. Example grids to illustrate a flexible groundwater modelling system to support local investigations within an agreed regional framework. The example shows the modification of an extended Swanscombe groundwater model (Case Study 1) to support (A) analysis of abstraction impact and river flows, and (B) detailed analysis of wellfield development. 


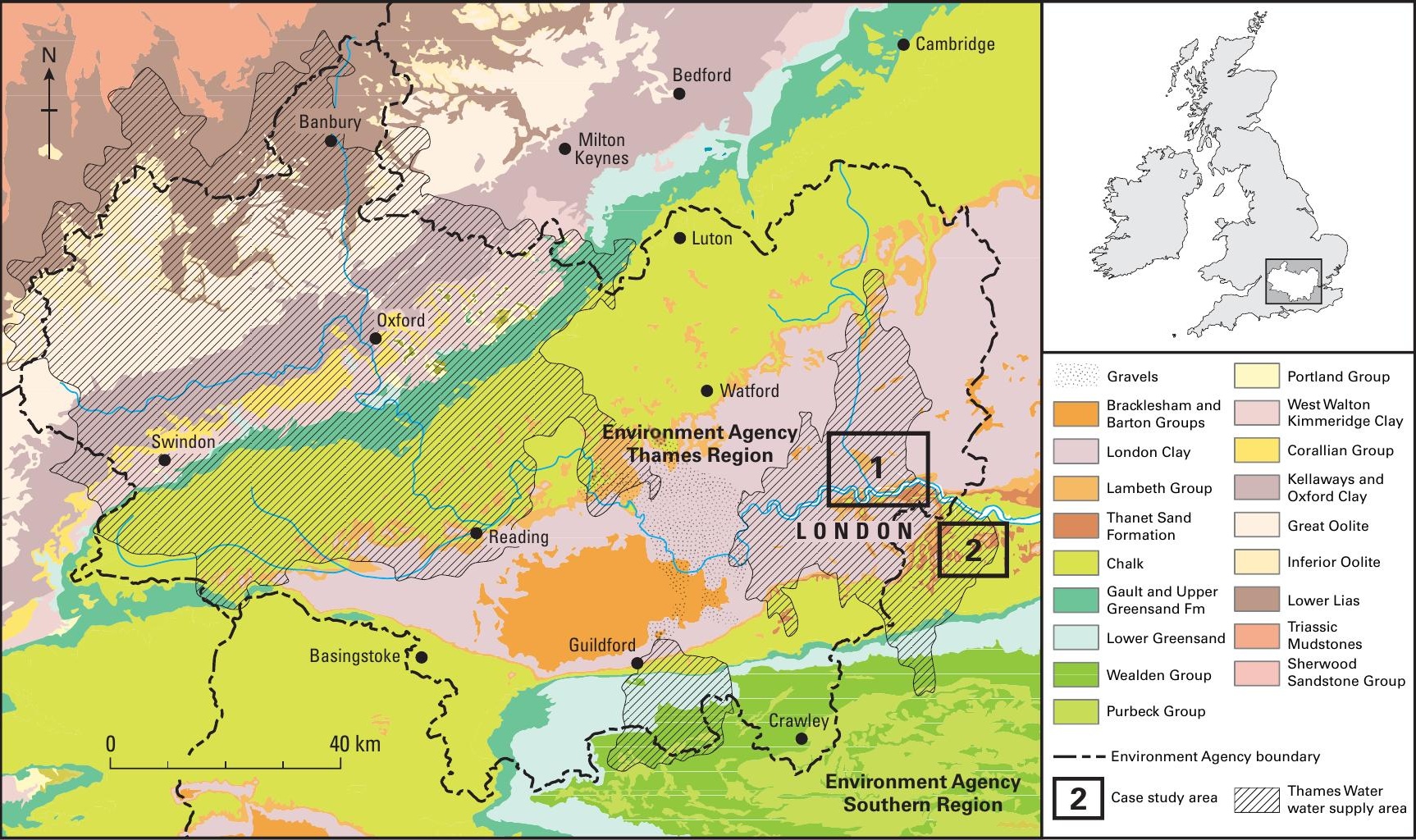




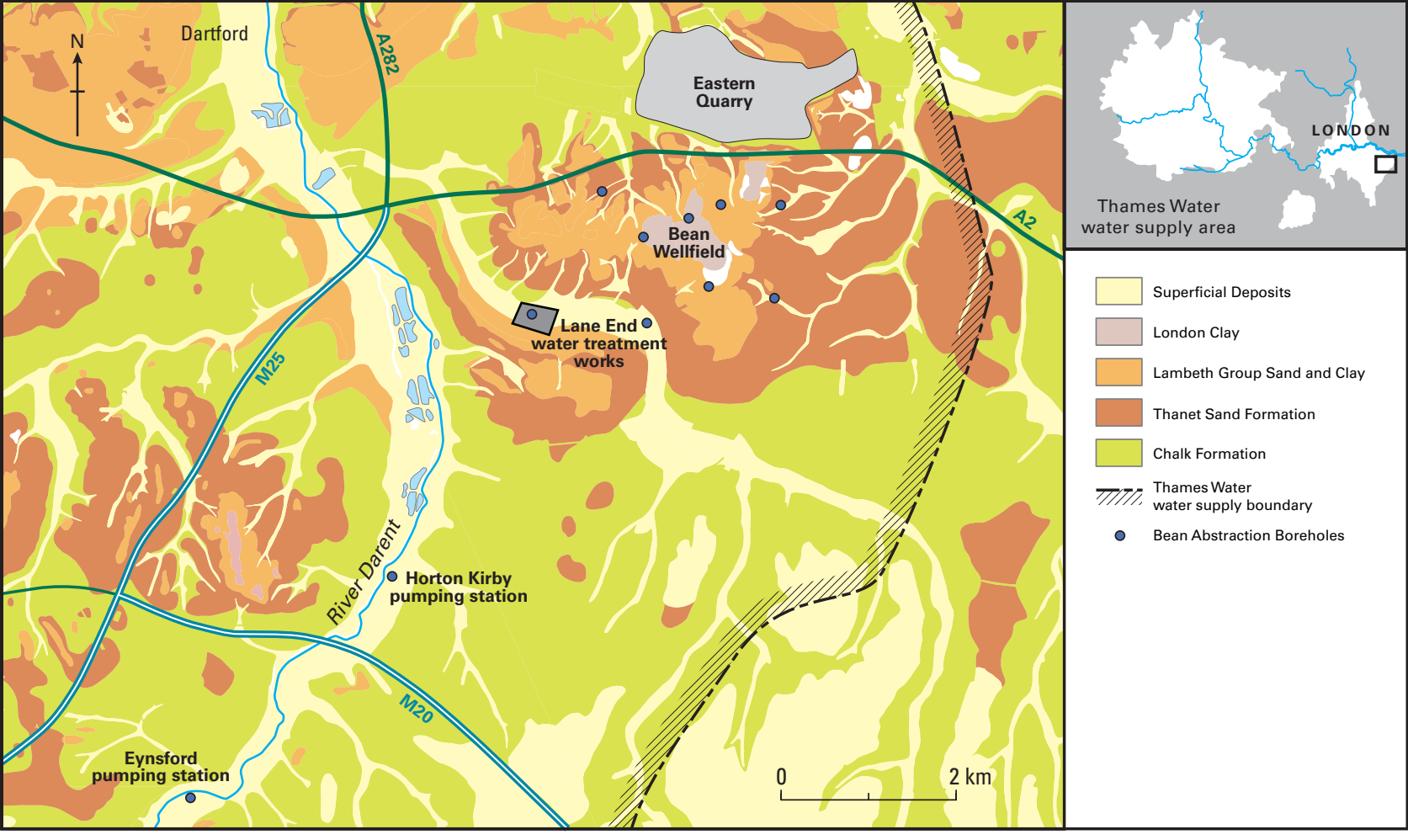




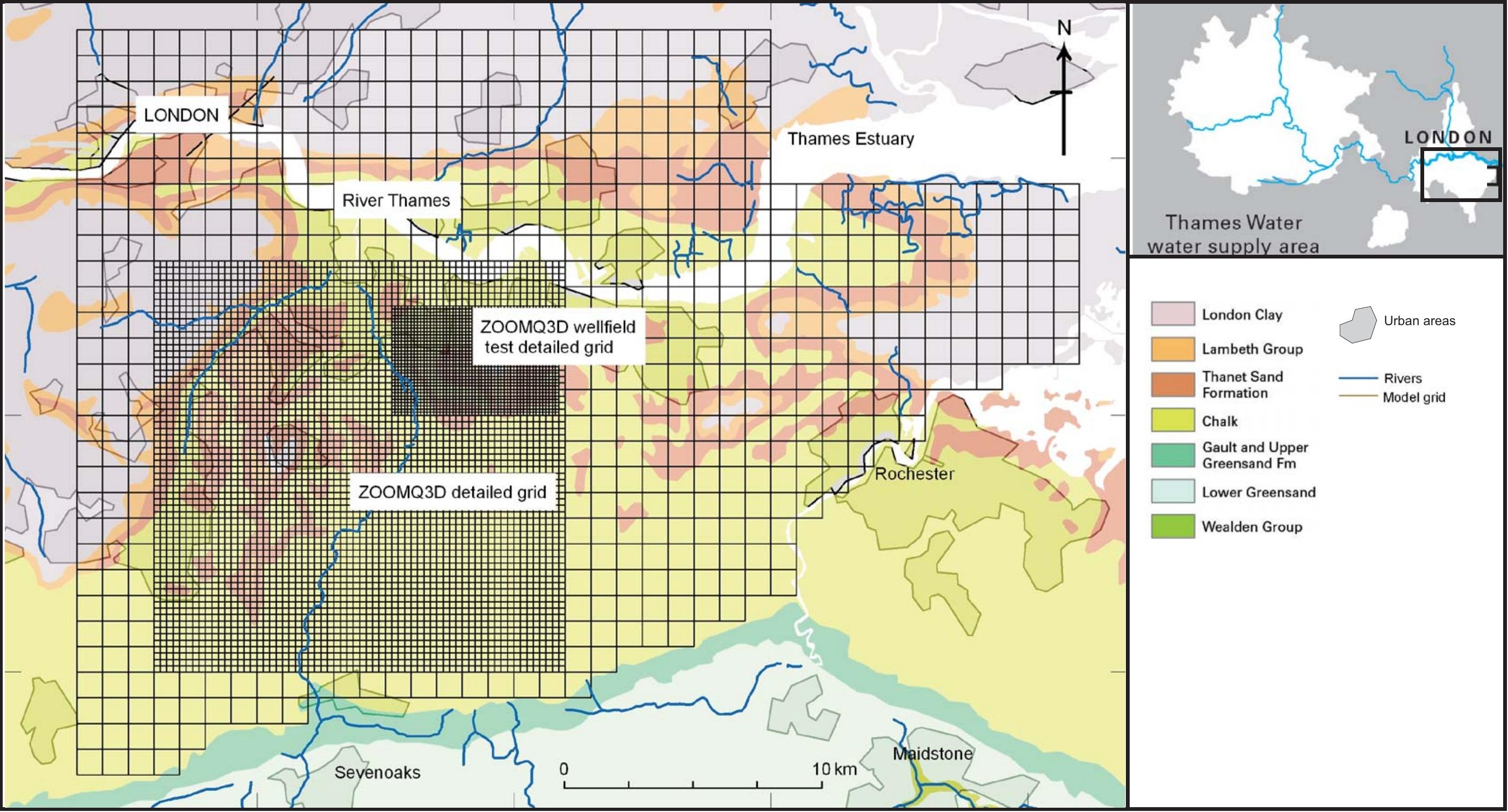




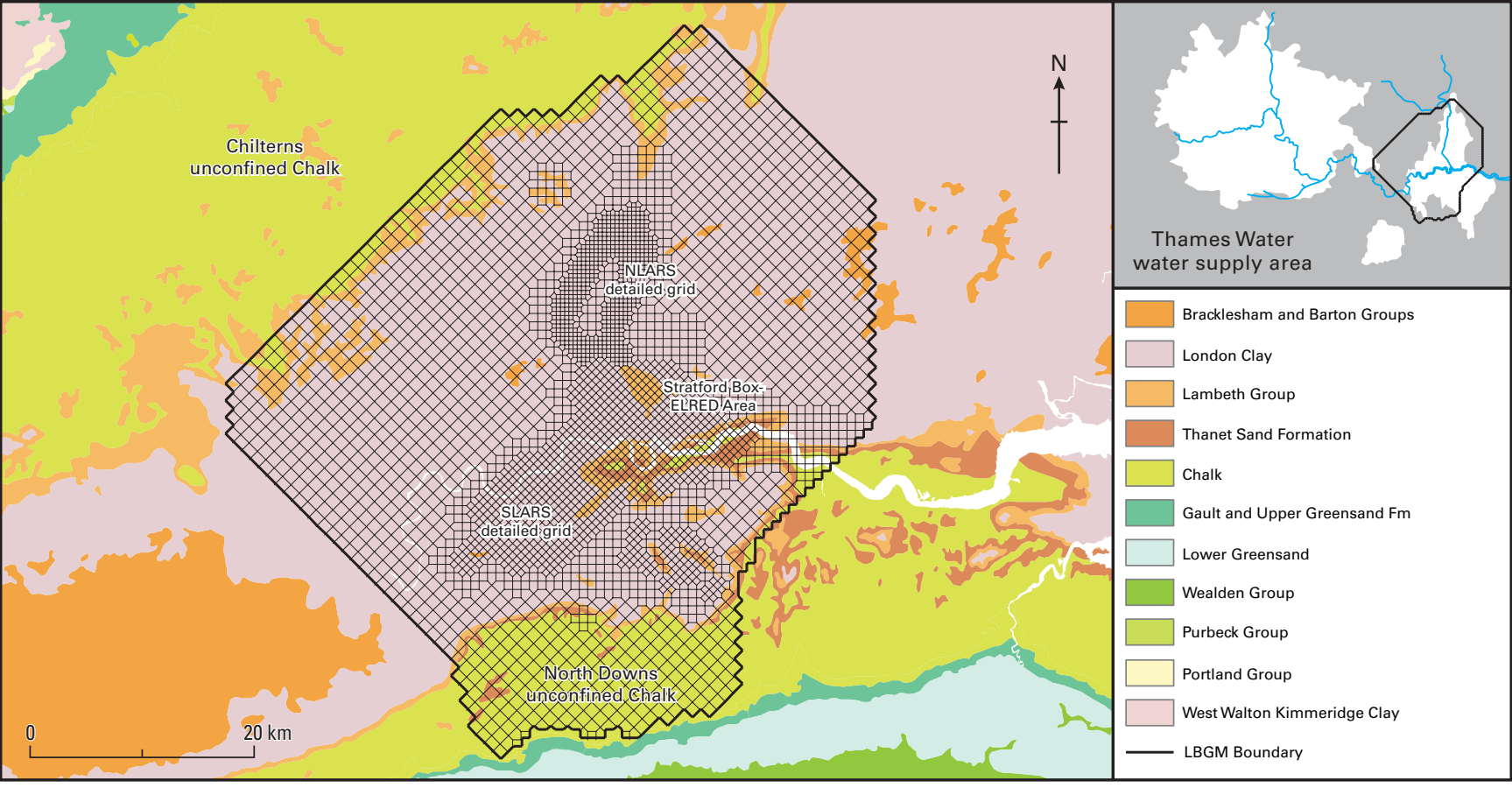

\begin{tabular}{|l|l|l|}
\hline Andrew Hughes June 2010 & Max W176mm H236mm \\
\hline Fig_5 - 1st Proof & Drawn by S D Ward 22/7/2011 \\
\hline Fig_5 - 2nd Proof & Altered by S D Ward 29/7/2011 \\
\hline- & - & \\
\hline
\end{tabular}




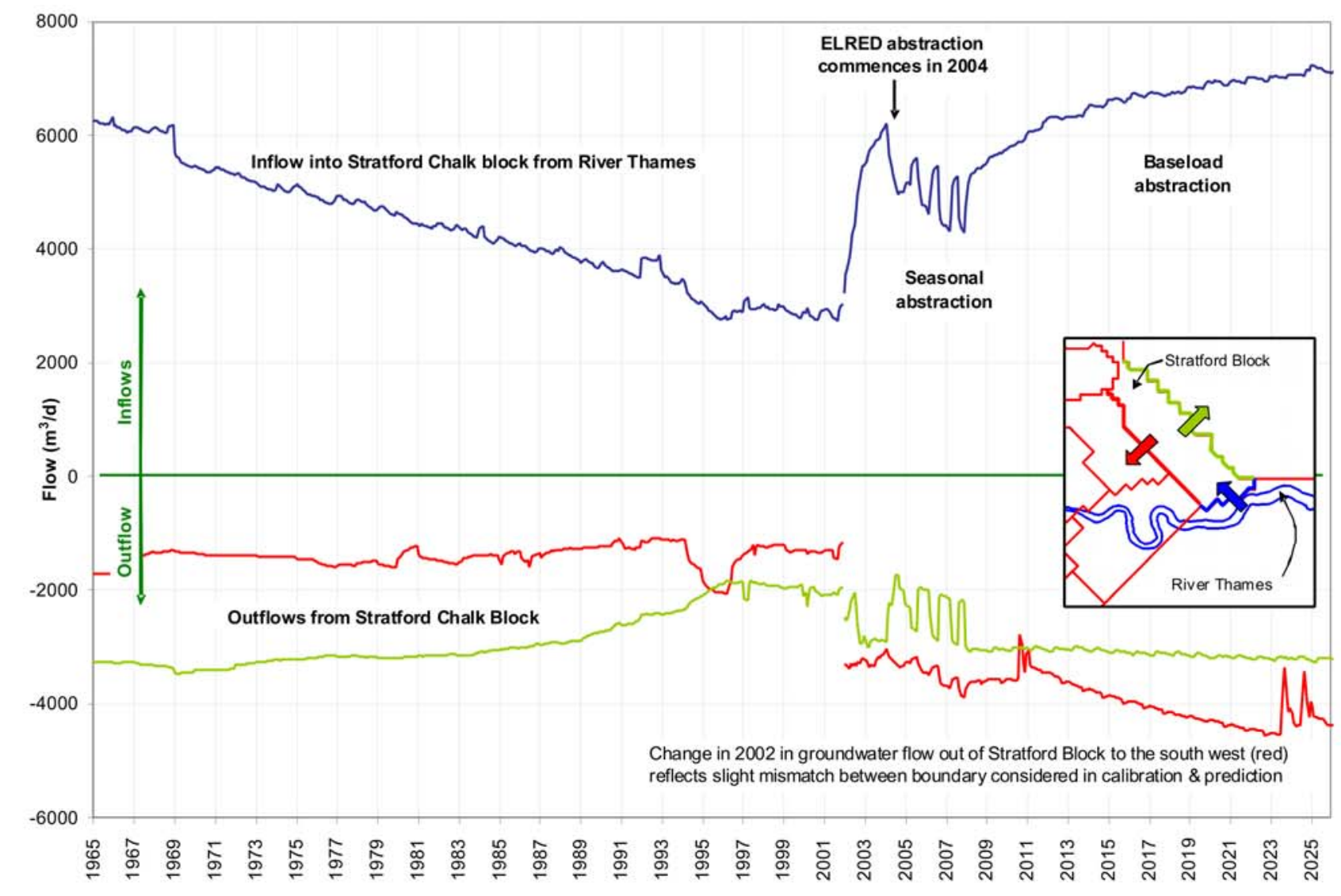



